\title{
Self-medication practices in riverside communities in the Brazilian Amazon Rainforest
}

\author{
Práticas de automedicação em comunidades ribeirinhas na Amazônia brasileira \\ Prácticas de automedicación en las comunidades de ribereña en la Amazonía brasileña
}

'Universidade Federal do Amazonas, Instituto de Saúde e Biotecnologia. Coari, Amazonas, Brazil.

"Universidade de São Paulo. São Paulo, São Paulo, Brazil.

How to cite this article: Gama ASM, Secoli SR. Self-Medication practices in riverside communities in the Brazilian Amazon Rainforest. Rev Bras Enferm. 2020;73(5):e20190432. doi: http://dx.doi.org/10.1590/0034-7167-2019-0432

Corresponding author:

Abel Santiago Muri Gama

E-mail: abelsmg@hotmail.com

EDITOR IN CHIEF: Antonio José de Almeida Filho ASSOCIATE EDITOR: Rafael Silva

Submission: 11-18-2019

Approval: 12-17-2019

\begin{abstract}
Objectives: to analyze the practice of self-medication and the associated factors in the riverside population of the Middle Solimões river region - Amazon rainforest. Methods: a cross-sectional population-based study conducted between April and July 2015, through interviews at home. Results: the prevalence of self-medication among the riverside population was $76.3 \%$. Analgesics and antibacterials were the main therapeutic classes used in self-medication. Selfmedication proved to be associated with the male gender, young people, not having sought the health service in the last month, longer commuting from the community to the urban area and the habit of consuming allopathic medicines on their own. Conclusions: self-medication among the riverside population of Coari - Amazon may reflect the need to seek self-care by people, with the use of allopathic medicines without prescription, mainly due to the restricted access to health services.
\end{abstract}

Descriptors: Self Medication; Self Care; Vulnerable Populations; Epidemiologic Studies; Rural Population.

\section{RESUMO}

Objetivos: analisar a prática de automedicação e os fatores associados na população ribeirinha da região do Médio Solimões - Amazonas. Métodos: estudo transversal de base populacional realizado entre abril a julho de 2015, por meio de entrevistas em domicílio. Resultados: a prevalência da automedicação entre os ribeirinhos foi de $76,3 \%$. Analgésicos e antibacterianos foram as principais classes terapêuticas consumidas na prática de automedicação. A automedicação mostrou-se associada ao sexo masculino, jovens, não ter procurado pelo serviço de saúde no último mês, maior tempo de deslocamento da comunidade à zona urbana e o hábito de consumo de medicamentos alopáticos por conta própria. Conclusões: a automedicação entre a população ribeirinha de Coari-Amazonas pode refletir a necessidade de busca do autocuidado pelas pessoas, com o uso de medicamentos alopáticos sem prescrição, sobretudo decorrente do restrito acesso aos serviços de saúde. Descritores: Automedicação; Autocuidado; Populações Vulneráveis; Estudos Epidemiológicos; População Rural.

\section{RESUMEN}

Objetivos: analizar la práctica de la automedicación y los factores asociados en la población ribereña de la región de Solimões Medio - Amazonas. Métodos: estudio transversal basado en la población realizado entre abril y julio de 2015, a través de entrevistas en el hogar Resultados: la prevalencia de la automedicación entre los habitantes de la ribera fue del $76,3 \%$. Los analgésicos y los antibacterianos fueron las principales clases terapéuticas utilizadas en la automedicación. Se demostró que la automedicación estaba asociada con el género masculino, los jóvenes, que no habían buscado el servicio de salud en el último mes, el mayor tiempo de viaje al área urbana y el hábito de consumir medicamentos alopáticos por su cuenta. Conclusiones: automedicación entre la población ribereña de Coari - Amazonas puede reflejar la necesidad de buscar el autocuidado de las personas, con el uso de medicamentos alopáticos sin receta, principalmente debido al acceso restringido a los servicios de salud.

Descriptores: Automedicación; Autocuidado; Poblaciones Vulnerables; Estudios Epidemiológicos; Población Rural. 


\section{INTRODUCTION}

The Brazilian Amazon rainforest has an area of approximately 5 million $\mathrm{km}^{2}$, with important climatic, social and economic variations that can impact the profile of morbidity and the use of medicines. The epidemiological profile of the Amazonian population is quite heterogeneous, including vector-borne diseases, such as malaria, dengue, cutaneous leishmaniasis and Diseases Related to Inadequate Sanitation (DRSAI - Doenças Relacionadas ao Saneamento Inadequado). Mortality is significantly caused by infectious and parasitic diseases ${ }^{(1-2)}$. Riverside populations living on the banks of rivers and lakes, often geographically isolated, are highly vulnerable to these health problems. In this way, the use of local practices, originating from popular wisdom, is frequently used to resolve the disease issues typical of the region ${ }^{(3)}$.

The limitations imposed by the Amazonian environment, especially of a climatic nature (flooding and ebbing of rivers), the continental geographic dimensions, added to the scarcity and imbalances in the distribution of health professionals restrict information about these populations, especially with regard to the way in which health care and self-medication are carried out.

According to the World Health Organization (WHO), self-medication represents an element of self-care, which is based on the selection and use of medicines by the individual, in order to treat diseases or self-recognized symptoms $s^{(4)}$. Globally, on a daily basis, individuals practice self-medication, regardless of countries of origin or age group $^{(5-10)}$. The possibility of causing disorders related to medications, such as medication errors, adverse reactions to medications and interactions between medications; to cause antimicrobial resistance; of causing the risk of masking evolutionary diseases and leading to unnecessary expenditure of financial resources, through the acquisition of inappropriate drugs, are some of the elements that contribute to the potentially unhealthy discussion about self-medication ${ }^{(11-12)}$.

Despite these considerations, in remote areas, self-care, understood as the individual capacity to take care and perform activities for their own benefit, in order to maintain health and well-being ${ }^{(13)}$, including the practice of self-medication, are especially encouraged in order to quickly relieve symptoms or minor illnesses without the need for medical consultations, especially due to the population's difficulty in accessing health services ${ }^{(14-15)}$.

Due to the high magnitude and divergent aspects regarding the impact on the population's health, the practice of self-medication was investigated in different regions of the globe. In Europe, studies conducted in urban areas, with subjects over 16 years old, showed a prevalence ranging from $11.7 \%$ to $77.4 \%{ }^{(16-19)}$. In developing countries, located in Asia and Africa, investigations carried out in urban and rural areas, with adults, showed rates between $8.9 \%$ and $92.7 \% \%^{(7,9,20-22)}$.

In Brazil, the practice of self-medication is frequent and does not depend on the region of the country ${ }^{(23-27)}$. Expressive prevalence came from studies carried out in the States of Pernambuco (77.0\%) ${ }^{(23)}$ and Piauí $(92.7 \%)^{(24)}$. Nationally, in urban areas, it became evident that self-medication occurs more frequently in less economically wealthy Brazilian regions ${ }^{(10)}$.

Despite the relative methodological differences, mainly to the recall period of self-medication, the contributing factors of this practice, in adult individuals, included male gender ${ }^{(17,28-29)}$, younger age groups ${ }^{(17-19)}$ or higher ${ }^{(8,16)}$ and poor perception of health ${ }^{(26)}$.
In the Amazon region, participation elucidation of variables of a geographical nature in the phenomenon of self-medication is essential. The time taken by the inhabitants to travel exclusively by river to health services and the distance between rural areas and municipalities can be influenced by climatic conditions, especially in the case of more distant communities. In the rainy season (Amazonian winter - flood), the riverside people have easier access to the urban area, in contrast, in the summer (drought), some communities become isolated and access to the urban area is restricted, making navigation difficult, even on small boats.

\section{OBJECTIVES}

To analyze the practice of self-medication and the associated factors in the riverside population of the Middle Solimões riverAmazonas region.

\section{METHODS}

\section{Ethical aspects}

The study was approved by the Research Ethics Committee of the Universidade de São Paulo School of Nursing (Opinion 33560914.0.0000.5392). Participants who consented to participate signed the Informed Consent Form (ICF).

\section{Study outlining and location}

The present investigation is part of the "Saúde, Medicamentose Automedicação em Ribeirinhos do Amazonas"- SAMARA, a populationbased cross-sectional study conducted with riverside residents in the rural area of the Middle Solimões region from April to July $2015^{(3)}$.

Coari is located in the central region of the state of Amazonas, on the middle channel of the Solimões River, with 84,762 inhabitants, with low population density, 1.3 people per $\mathrm{km}^{2(30)}$. The inhabitants of the rural area are distributed in 135 riverside communities, which are dispersed along the banks of the Solimões River, lakes and streams, in areas of dry land and floodplains. The municipality is geographically isolated and access is made exclusively by river or air.

For health care, in 2015, the municipality had a medium complexity hospital (105 beds), 12 Basic Health Units (BHU), a Tropical Medicine Institute, a hospital boat to offer assistance to riverside communities, a Central Clinical Analysis Laboratory, an Emergency Service, a Health Surveillance Center, a Polyclinic and a Psychosocial Care Center (CAPS - Centro de Atenção Psicossocial) $)^{(31)}$. In rural areas, riverside communities, or groups of two or three smaller communities, have Community Health Agents (CHA). CHA are local residents who know the inhabitants and the reality of the community, and play a fundamental role in the detection and, often, treatment of specific health problems in the region.

\section{Sample}

The probabilistic sample, by conglomerate, was composed of 470 participants from 24 communities distributed in 8 regions of the rural zone of Coari. Adults $\geq 18$ years old, who were at the time of application of the questionnaire were included. The sample size calculation was based on the number of riverside communities 
covered by the Municipal Health Department of Coari $(n=135)$, in order to guarantee the representativeness of the territorial area of the research and the number of inhabitants of these communities $(n=10,333)$. The prevalence of self-medication equal to $50 \%$ and $a$ safety level of $95.0 \%$ were considered. Adjustment was made for the finite population and a $20 \%$ loss was admitted. The sample was designed in two stages, such as random selection of the riverside community in each of the regions, with probability proportional to the population of the community; random selection of residences in each community drawn. In randomly selected households, people aged 18 or over were interviewed.

\section{Data collection questionnaire}

The information was collected through a standardized and previously tested questionnaire, composed of socioeconomic and demographic data, access to health services, alcohol consumption and smoking habits, self-reported illnesses and information on the use of medicines. A pilot study was carried out in order to evaluate the questionnaire and its adequacy to the riverside reality. Subsequently, training of the team was carried out ${ }^{(3)}$.

\section{Study variables}

Self-medication practice was considered as a dependent variable, which was assessed by using at least one medication without a medical or dental prescription, in the last 30 days. To measure the variable, the following questions were used: did you take any medication in the last 30 days? What is (are) the name (s) of the medication (s) you are taking or have taken in the last 30 days? Who indicated the medication (s)? Why did you use the medicine?

The independent variables were of a demographic nature (gender and age), socioeconomic (education, monthly family income), access to health services (distance and time to access health services, frequency of trips to the urban area and demand for health services) health), self-reported health (perception of health, health problem, use of alcohol and tobacco) and use of medicines.

\section{Data analysis}

The data were stored in the program SPSS (Statistical Package for Social Sciences) 20.0 for Windows, with double data entry. Allopathic medicines were classified using the Anatomical Therapeutic Chemical Classification (ATC) system, adopted by WHO and recommended in studies on the use of medicines (levels 2 and 5$)^{(32)}$.

For qualitative variables, descriptive statistics (absolute and relative frequencies) were used. For the quantitative variables, measures of central tendency and dispersion were calculated. For data bivariate analysis, the Chi-Square Test or Fischer's Exact Test was used. For categorical variables, the t test of Student or Wilcoxon-Mann-Whitney was used for numerical variables.

In multivariate binary logistic regression, the dependent variable was self-medication. The independent variables that entered the model were those with a value of $(p<0.20)$ in the Chi-Square Test. The regression analyzes followed a hierarchical model, so that those with significance $(p<0.05)$ in the adjustment with the other variables belonging to the same hierarchical level remained in the model.

\section{RESULTS}

Four hundred ninety-two subjects were interviewed, most of whom (70.3\%) used at least one medication. The prevalence of self-medication was $76.3 \%$ (95\% Cl: 71.6 - 80.5), which was higher among male subjects, young people, who live in places more distant from the urban area, who need more time (in hours) to access health services, which tend to visit the urban area less frequently and who did not seek health services, in the last 30 days (Table 1).

Self-medication frequency was higher in subjects who rated their health as good or very good, reported some health problem in the last 30 days, who are in the habit of using medications on their own and who stock up on medications at home (Table 2).

The consumption of 70 different types of medication was reported by the sample, which were used according to the selfmedication modality $(65.4 \% ; 360)$ and according to medical prescription (34.6\%; 190).

Table 1 - Consumption of medicines according to demographic, socioeconomic variables and access to health services, Coari, Amazonas, Brazil, 2015

\begin{tabular}{|c|c|c|c|}
\hline \multirow[b]{2}{*}{ Variables } & \multicolumn{2}{|c|}{ Consumption of Medicines } & \multirow{2}{*}{ value } \\
\hline & $\begin{array}{c}\text { Self-medication } \\
n=264(\%)\end{array}$ & $\begin{array}{c}\text { Prescribed } \\
n=82(\%)\end{array}$ & \\
\hline Gender & & & 0.024 \\
\hline Male & $118(81.9)$ & $26(18.1)$ & \\
\hline Female & $146(72.3)$ & $56(27.7)$ & \\
\hline Age (years) & & & 0.006 \\
\hline 18 to 39 years & $162(82.7)$ & 34 (17.3) & \\
\hline 40 to 59 years & $75(68.8)$ & $34(31.2)$ & \\
\hline$\geq 60$ & $27(65.9)$ & $14(34.1)$ & \\
\hline Mean \pm Standard Deviation & $36.7 / 15.0$ & $44.1 / 17.4$ & \\
\hline Schooling (full years of study) & & & 0.940 \\
\hline Did not attend school & $26(78.8)$ & $7(21.2)$ & \\
\hline 1 to 4 & $77(75.5)$ & $25(24.5)$ & \\
\hline 5 to 9 & $74(74.7)$ & $25(25.3)$ & \\
\hline$\geq 10$ & $87(77.7)$ & $25(22.3)$ & \\
\hline Mean \pm Standard Deviation & $7.5 / 4.3$ & $7.2 / 4$ & \\
\hline Monthly family income (Minimum & & & 0.167 \\
\hline Wage $)^{t+}$ & & & \\
\hline$<1$ & $95(70.9)$ & $39(29.1)$ & \\
\hline 1 to 2 & $113(80.1)$ & $28(19.9)$ & \\
\hline$>2$ & $56(78.9)$ & $15(21.1)$ & \\
\hline Mean \pm Standard Deviation & $1.5 / 1.6$ & $1.2 / 0.9$ & \\
\hline Household residents & & & 0.086 \\
\hline 1 to 5 & $120(72.7)$ & $45(27.3)$ & \\
\hline$\geq 6$ & $144(79.6)$ & $37(20.4)$ & \\
\hline Distance to access health services ( $\mathrm{km})$ & & & 0.028 \\
\hline$<50$ & $121(71.2)$ & $49(28.8)$ & \\
\hline 50 to 100 & $77(77.0)$ & $23(23.0)$ & \\
\hline$>100$ & $66(86.8)$ & $10(13.2)$ & \\
\hline Mean \pm Standard Deviation & $66.4 / 56.6$ & $47.9 / 45.4$ & \\
\hline Time to access health services (hour) & & & 0.001 \\
\hline$<1$ & $20(54.1)$ & $17(45.9)$ & \\
\hline 1 to 4 & $131(75.3)$ & $43(24.7)$ & \\
\hline$>$ of 4 & $113(83.7)$ & $22(16.3)$ & \\
\hline Mean \pm Standard Deviation & 4.6/3.6 & $3.3 / 2.7$ & \\
\hline Frequency of trips to the urban area & & & 0.406 \\
\hline$>$ than once a month & $76(71.7)$ & $30(28.3)$ & \\
\hline Once a month & $169(78.2)$ & $47(21.8)$ & \\
\hline Don't usually go & $19(79.2)$ & $5(20.8)$ & \\
\hline Search for health service & & & 0.001 \\
\hline Yes & $63(61.2)$ & $40(38.8)$ & \\
\hline No & $201(82.7)$ & $42(17.3)$ & \\
\hline
\end{tabular}

Note: ${ }^{+}$Chi-Square Test $(<0.005) ;{ }^{+\dagger}$ Minimum Wage for April 2015 (788 reais (reais is the Brazilian currency, which corresponds to approximadetly 188 US dollars)); ${ }^{+t+}$ More than once a month: every day; up to 3 times a week; once a week; once a fortnight. 
Table 2 - Consumption of medicines according to self-reported health conditions and habits related to the use of medicines at home, Coari, Amazonas, Brazil, 2015

\begin{tabular}{|c|c|c|c|}
\hline \multirow[b]{2}{*}{ Variables } & \multicolumn{2}{|c|}{ Consumption of Medicines } & \multirow[b]{2}{*}{$p$ value $^{\dagger}$} \\
\hline & $\begin{array}{l}\text { Self-medication } \\
n=264(\%)\end{array}$ & $\begin{array}{c}\text { Prescribed } \\
n=82(\%)\end{array}$ & \\
\hline Self-perceived health & & & 0.049 \\
\hline Very good/good & $123(82.0)$ & $27(18.0)$ & \\
\hline Regular/very bad/bad & $141(53.4)$ & $7(46.6)$ & \\
\hline Health problem & & & 0.272 \\
\hline Yes & $228(77.0)$ & $68(23.0)$ & \\
\hline No & $36(72.0)$ & $14(28.0)$ & \\
\hline Alcohol use & & & 0.030 \\
\hline Yes & $74(84.1)$ & $14(15.9)$ & \\
\hline No & $190(73.6)$ & $68(26.4)$ & \\
\hline Smoking & & & 0.055 \\
\hline Yes & $79(70.5)$ & $33(29.5)$ & \\
\hline No & $185(79.1)$ & 49 (20.9) & \\
\hline Habit of consumption of allopathic medicines on their own & & & 0.001 \\
\hline Yes & $244(80.0)$ & $61(20.0)$ & \\
\hline No & $20(48.8)$ & $21(51.2)$ & \\
\hline Joint use of allopathic medicine and medicinal plants & & & 0.669 \\
\hline Yes & $222(74.7)$ & $42(25.3)$ & \\
\hline No & $224(77.8)$ & $40(22.2)$ & \\
\hline Number of medicines used & & & 0.446 \\
\hline 1 & $162(76.8)$ & $49(23.2)$ & \\
\hline 2 to 4 & $102(75.6)$ & $33(24.4)$ & \\
\hline Mean \pm Standard Deviation & $1.4 / 0.7$ & $1.6 / 0.8$ & \\
\hline Stores medicines at home & & & 0.086 \\
\hline Yes & $117(78.0)$ & $33(22.0)$ & \\
\hline No & $147(75.0)$ & $49(25.0)$ & \\
\hline
\end{tabular}

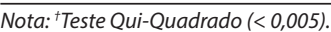

Table 3 - Medicines reported according to consumption modality and therapeutic/pharmacological subgroup Anatomical Therapeutic Chemical Classification - Level 2, Coari, Amazonas, Brazil, 2015

\begin{tabular}{|c|c|c|}
\hline \multirow{2}{*}{$\begin{array}{l}\text { Therapeutic/pharmacological subgroup - } \\
\text { Anatomical Therapeutic Chemical Classification - Level } 2\end{array}$} & \multicolumn{2}{|c|}{ Consumption modality } \\
\hline & $\begin{array}{l}\text { Self-medication } \\
\qquad \mathrm{n}=360(\%)\end{array}$ & $\begin{array}{l}\text { Prescribed } \\
n=190(\%)\end{array}$ \\
\hline Analgesics & $207(57.5)$ & $36(19.0)$ \\
\hline Antibacterials for systemic use & $47(13.0)$ & $23(12.1)$ \\
\hline Anti-inflammatory and antirheumatic products & $34(9.4)$ & $19(10.0)$ \\
\hline Antithrombolytic agents & $19(5.2)$ & $9(4.7)$ \\
\hline Anti-anemic preparations & $10(2.7)$ & $9(4.7)$ \\
\hline Medicines for acid disorders & $8(2.2)$ & $19(10.0)$ \\
\hline Vitamins & $7(1.9)$ & $7(3.7)$ \\
\hline Anthelmintics & $4(1.1)$ & --- \\
\hline Corticosteroids for systemic use & $3(0.8)$ & $1(0.5)$ \\
\hline Hormones and modulators of the genital system & $3(0.8)$ & $4(2.1)$ \\
\hline Muscle relaxants & $2(0.6)$ & $1(0.5)$ \\
\hline Mineral supplements & $2(0.6)$ & $2(1.1)$ \\
\hline Intestinal agents, anti-diarrheal, anti-inflammatory/anti-infectious & $2(0.6)$ & $3(1.6)$ \\
\hline Constipation medications & $2(0.6)$ & --- \\
\hline Agents acting on the renin-angiotensin system & $2(0.6)$ & $20(10.6)$ \\
\hline Antipruritic agents, including antihistamines, anesthetics, other & $2(0.6)$ & --- \\
\hline Lipid-modifying agents & $1(0.3)$ & $4(2.1)$ \\
\hline Antifungals for dermatological use & $1(0.3)$ & $3(1.6)$ \\
\hline Antihistamines for systemic use & $1(0.3)$ & --- \\
\hline Medicines for gastrointestinal disorders & $1(0.3)$ & $5(2.6)$ \\
\hline Ophthalmological & $1(0.3)$ & --- \\
\hline Preparations for cough and cold & $1(0.3)$ & $1(0.5)$ \\
\hline Antiparkinsonian agents & --- & $1(0.5)$ \\
\hline Antiprotozoals & --- & $2(1.1)$ \\
\hline Antiemetics & --- & $1(0.5)$ \\
\hline Calcium-channel blockers & --- & $3(1.6)$ \\
\hline Diuretics & --- & $5(2.6)$ \\
\hline Psychoanaleptics & --- & $1(0.5)$ \\
\hline Psycholeptics & --- & $1(0.5)$ \\
\hline Beta-blocking agents & --- & $3(1.6)$ \\
\hline Medicinal products for obstructive airway diseases & --- & $1(0.5)$ \\
\hline Medicinal products used in diabetes & --- & $6(3.2)$ \\
\hline Total & $360(100.0)$ & $190(100.0)$ \\
\hline
\end{tabular}

Analgesics (57.5\%) and antibacterials of systemic use $(13.0 \%)$ were the main therapeutic classes used in self-medication. Among the drugs prescribed, the drugs used for cardiovascular problems prevailed (21.1\%) (Table 3). Sodium dipyrone and paracetamol were the most consumed analgesics in self-medication, while the most consumed antibiotics were amoxicillin and tetracycline (data not shown in the table).

The main self-reported reason for practicing self-medication was the presence of pain in general (58.1\%) (headache, back pain, muscle pain, joint pain and abdominal pain), followed by flu and related symptoms (fever and cough) (17.2\%) and inflammation (7.2\%). The drugs most used to relieve pain and inflammatory processes were analgesics, especially non-steroidal anti-inflammatory drugs (ASA, diclofenac, ibuprofen, dipyrone). Antibacterial for systemic use (amoxicillin, ampicillin and sulfadiazine) have been reported in unexpected health conditions, such as pain, flu, inflammation, fever and gastrointestinal disorders (Table 4).

Among self-medicated individuals, it was observed that, mostly, consumption occurred on their own initiative (69.4\%). Clerks and pharmacists (14.5\%), neighbor, friend, family member or others $(8.1 \%)$, nurse $(4.7 \%)$ and CHA (3.3\%) also participated in the indication of the medicine (data not presented in a table). 
Table 4 - Health reasons reported according to the medicines used in the practice of self-medication, Coari, Amazonas, Brazil, 2015

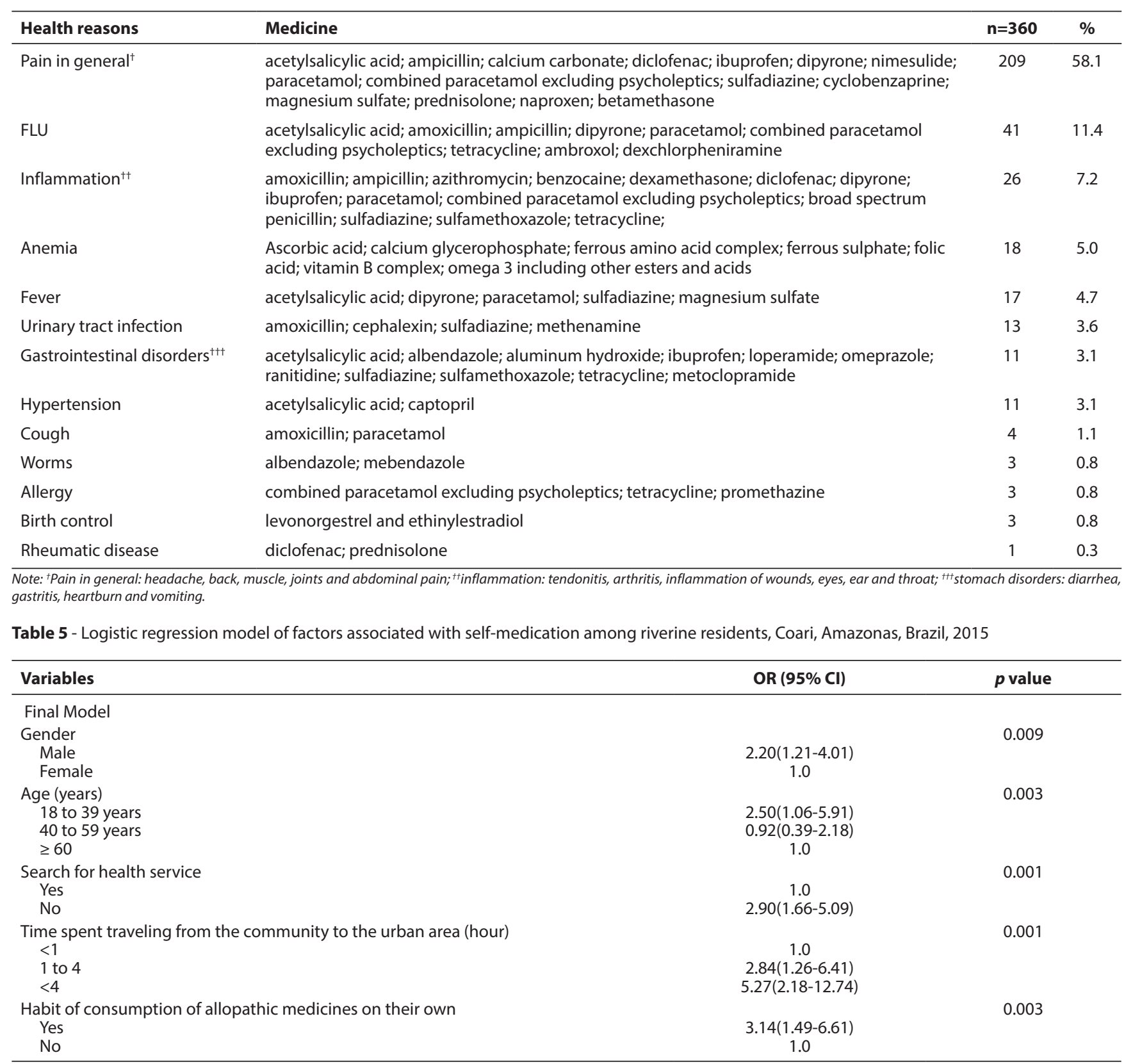

The variables that showed independent associations with the practice of self-medication in the final regression model were male $(\mathrm{OR}=2.20 ; \mathrm{Cl}=1.21-4.01)$; age between 18 to 39 years $(\mathrm{OR}=2.50$; $\mathrm{Cl}=1.06-5.91)$; not having sought the health service in the last month $(\mathrm{OR}=2.90 ; \mathrm{Cl}=1.66-5.09)$; time of commuting from the community to the urban area between 1 and $4 \mathrm{~h}(\mathrm{OR}=2.84 ; \mathrm{Cl}=1.26-6.41)$ time greater than $4 \mathrm{~h}(\mathrm{OR}=5.27 ; \mathrm{Cl}=2.18-12,74)$; habit of consuming allopathic medication on their own (OR=3.14; $\mathrm{Cl}=1.49-6.61)$ (Table 5).

\section{DISCUSSION}

Overall, the study pointed out that the practice of self-medication was high among riverside residents, which was caused, especially by the presence of pain complaints from different origins. The main drugs used in the self-medication modality were analgesics, antimicrobials and anti-inflammatory drugs. The factors associated with self-medication were male gender, people aged 18 to 39 years old, the fact that they did not seek health care and a longer time (in hours) of commuting between the community and the urban area.

The prevalence of self-medication detected among the riverside inhabitants of Coari (76.3\%), was close to findings from studies carried out in rural areas, in developing countries such as Pakistan $(85.0 \%)^{(20)}$, Uganda $(76,0 \%)^{(9)}$, Nigeria $(78.9 \%)^{(21)}$ and in Brazil, in the State of Pernambuco $(77.0 \%)^{(23)}$.

Although there are differences in Brazil, especially cultural and health practices, in relation to the Brazilian regions and developing countries that presented high rates of self-medication, it is possible that these settings have similar characteristics regarding the limitations of government control in the marketing of medicines, in addition to the practice of self-care with the 
support of medication, especially due to the restricted access to health services ${ }^{(33)}$.

In remote areas of the globe, similar to what happens with the riverside communities of the Amazon, whose access to the urban area occurs exclusively by river, the scarcity and important imbalance in the distribution of health professionals impact the population's access to health care $^{(34)}$. These explanations seem to be confirmed by the respondents in questions regarding the dynamics of self-medication practice.

In accordance with previous studies, analgesics (57.5\%) were the most consumed drugs in the self-medication modality ${ }^{(7-8,18,21,23-24,26)}$. These agents are freely available on the market, do not require a prescription and are available on drugstore and pharmacy shelves. In addition, there is often the presence of this therapeutic class in medication boxes in homes and the cost is relatively low, making it possible to purchase ${ }^{(35)}$. These drugs, due to the range of therapeutic effects - analgesic, anti-inflammatory and antipyretic, represent a quick and practical way to improve uncomfortable symptoms, especially in the Amazon, whose majority of riverside dwellers live far from the urban area and have limited access health services, which are located in the municipality.

In line with the therapeutic class most used by riverine residents, pain symptoms, especially back and muscle pain, were the main reasons that led to the consumption of over-the-counter medications (58.1\%), corroborating the findings of previous investigations ${ }^{(7-8,20,22,24)}$. At this point, it is necessary to consider the characteristics of the studied group, especially the fact that men were more likely to selfmedicate $(\mathrm{OR}=2.2)$. This rather dissonant finding in the literature, in which women are often at greater risk of self-medication ${ }^{(10)}$, may be due to some explanations. In Coari, most subjects live exclusively from fishing and agriculture, an activity aimed mainly at men. These work activities, which impact on the increase in weight overload, possibly contributed to the consumption of painkillers in the selfmedication modality. Fishing requires an important physical effort to transport the boxes with fish and ice used to preserve the product. In agriculture, the physical effort can be even greater during the transport of the products harvested in the plantations or "fields" (manioc) or in the forest (açaí (açaí is a deep purple, edible berry of a Central and South American palm tree), chestnut, game) to the homes or boats. In this Amazon region, in general, there is no aid for animal or mechanical traction in subsistence agriculture ${ }^{(3)}$. In addition, men tend to seek less health services and often seek solutions that allow them to resolve their illnesses in the community and quickly. This problem-solving strategy can be used to avoid economic losses and the family's survival during the period of inactivity caused by the disease, especially in the case of inhabitants of communities more distant from the urban area.

Despite the regulations of the Brazilian National Health Surveillance Agency (ANVISA - Agência Nacional de Vigilância Sanitária), which in theory prohibits the sale of antibiotics without a prescription ${ }^{(36)}$, it became evident that systemic antibacterials represented the second most consumed therapeutic group without prescription by riverside residents (13.0\%), exceeding the prescribed use (12.1\%). At this point, it is necessary to consider the self-reported reasons, which included unexpected health conditions for antibiotic therapy. These findings allow us to express that there was an inappropriate use of antibiotics, an aspect that can impact not only the unnecessary use of financial resources in the acquisition of these products, the issues of antimicrobial resistance, but especially the occurrence of adverse reactions to $\operatorname{drugs}^{(37)}$. The practice of self-medication with antimicrobials, in Coari and in countries like Asia ${ }^{(20,22)}$ and $\mathrm{Africa}^{(21)}$, which also have a low Human Development Index (HDI), may be related to issues involving the the health care system. Users often have the false belief of a cure through the use of antibiotics - a strong medicine capable of solving all ills ${ }^{(38)}$. On the other hand, health professionals who are not qualified to prescribe (pharmacists, nurses) and $\mathrm{CHA}$, often also indicate the use of these agents. Additionally, government control of the commercialization of antimicrobials is quite precarious ${ }^{(6)}$. In Coari, antibiotics are dispensed by pharmacies without a prescription ${ }^{(33)}$. This finding, although not from robust evidence, is in line with the fact that, in this survey, pharmacists or clerks indicated over-the-counter medications.

The life dynamics of the riverside population, expressed in some findings of the present investigation, contributes to the understanding of the practice of self-medication as a possible self-care strategy in a context in which there are limitations, especially of a geographical nature.

Young adults represented the age group associated with selfmedication. Despite the controversy of publications regarding this variable, possible explanations contribute to understanding in the Amazon. Considering the socio-cultural characteristics of riverside residents and limited access to health services, it is possible for older adults to use natural resources (medicinal plants) as an alternative to medical resources and the use of allopathic medicines. On the other hand, among young adults, who generally access the urban area more often, have a greater opportunity to be exposed to information about medicines (smartphones, radios, television), there is less occurrence of health problems, an aspect that it can contribute in reducing the demand for health services, in the search for practical and quick solutions such as self-medication, it seems very appropriate. These arguments are congruent with the findings that indicated that subjects who did not seek health services in the last month were 2.9 times more likely to self-medicate. Self-medication seems to be an alternative that substitutes medical attention for riverside residents. These findings are in line with a study carried out with Latin American immigrants who point out that the longer the time without seeking health services, the greater the risk of self-medication ${ }^{(16)}$.

The commute time from the community to the urban area (measured in hours) was a predictor of self-medication. Previous studies have shown that longer waiting times for healthcare services contribute to self-medication ${ }^{(39-40)}$. Due to the great distances of the community to the municipality; the time spent traveling, which is carried out exclusively by river; from the lack of health care posts in the investigated communities, it is possible that the only plausible alternative of care, especially in acute disorders (for example, diarrhea, vomiting, fever) and major discomfort such as pain, is self-medication.

\section{Study limitations}

The study had limitations regarding the peculiarities of the research developed in the Amazon context. Data collection took place during the period of river floods, an aspect that, on the one hand, enabled access to distant communities, but limited the identification of the profile of general medication consumption. It is possible that the results will be different when the investigation is repeated during 
the drought period, whose pattern of illness in the population may be different. Similar to studies on self-medication, the choice about the recall period (30 days) may have underestimated the prevalence of the phenomenon, especially in cases where the reason for using the medication was considered unimportant by the user.

\section{Contributions to nursing, health and public policies}

Knowledge of the practice of self-medication in the riverside population opens up possibilities for discussions about the responsible use of medicines, which requires the participation of a group of health professionals and public policy managers in the Amazon region. Guidance from $\mathrm{CHAs}$ on medications most consumed by the population and the risks associated with them (antimicrobial resistance, adverse reactions and drug interactions, especially with herbal medicines) is also essential, especially since a significant part of communities does not have easy access to health services. In this context, the participation of nurses is unique, since this professional, through his own training, can stimulate the riverside community to develop self-care, such as the increase of elements of popular knowledge (such as the use of plants) and individual expectations, in order to prevent possible adverse events related to drugs.

\section{CONCLUSIONS}

In the riverside population of Coari - Amazonas, the high prevalence of the practice of self-medication performed, especially with consumption of painkillers, used by young adults, in health problems related to work activities, may reflect the need to seek self-care. The restrictions on access to health services, caused by issues of a geographical, economic and organization of health services in the region, certainly favored the practice of self-medication as, perhaps, the only alternative for managing health itself. In this context, health professionals (doctors, pharmacists and nurses) and CHWs, who often represent the only support for solving health problems in the community, play a fundamental role. Community education about the problems arising from the inappropriate use of medicines can contribute to the promotion of responsible self-medication, since this practice seems to be vital in remote areas such as the Brazilian Amazon.

\section{FUNDING/ACKNOWLEDGMENT}

Fundação de Amparo à Pesquisa do Estado do Amazonas - FAPEAM.

\section{REFERENCES}

1. Freitas CM, Giatti LL. Indicadores de sustentabilidade ambiental e de saúde na Amazônia Legal. Cad Saúde Pública. 2009;25(6):1251-1266. doi: 10.1590/S0102-311X2009000600008

2. Viana RL, Freitas CM, Giatti LL. Saúde ambiental e desenvolvimento na Amazônia legal: indicadores socioeconômicos, ambientais e sanitários, desafios e perspectivas. Saude Soc. 2016;25(1):233-246. doi: 10.1590/S0104-12902016140843.

3. Gama ASM, Fernandes TG, Parente RCP, Secoli SR. Inquérito de saúde em comunidades ribeirinhas do Amazonas, Brasil. Cad Saúde Pública. 2018;34(2):e00002817. doi: 10.1590/0102-311X00002817

4. World Health Organization. The Role of the pharmacist in self-care and selfmedication[Internet]. Netherlands: WHO; 1998[cited 21 May 2019]. Available from: http://apps.who.int/medicinedocs/ver/d/Jwhozip32e/\#Jwhozip32e

5. Aziz MM, Masood I, Yousaf M, Saleem H, Ye D, Fang Y. Pattern of medication selling and self-medication practices: a study from Punjab, Pakistan. PloS One. 2018;22;13(3):e0194240. doi: 10.1371/journal.pone.0194240

6. Kumar N, Kanchan T, Unnikrishnan B, Rekha T, Mithra P, Kulkarni V, et al. Perceptions and practices of self-medication among medical students in coastal South India. PloS One. 2013;8(8):e72247. doi: 10.1371/journal.pone.0072247

7. Afridi MI, Rasool G, Tabassum R, Shaheen M, Siddiqullah, Shujauddin M. Prevalence and pattern of self-medication in Karachi: a community survey. Pak J Med Sci. 2015;31(5):1241-5. doi: 10.12669/pjms.315.8216

8. Carrera-Lasfuentes P, Aguilar-Palaciob I, Roldánd EC, Fumanalb SM, Hernandez MJR. Consumo de medicamentos ver población adulta: influencia del autoconsumo. Aten Primaria. 2013;45(10):528-35. doi: 0.1016/j.aprim.2013.05.006

9. Ocan M, Bwanga F, Bbosa GS, Bagenda D, Waako P, Ogwal-Okeng J, et al. Patterns and predictors of self-medication in northern Uganda. PloS One. 2014;9(3):e92323. doi: 10.1371/journal.pone.0092323

10. Arrais PSD, Fernandes MEP, da Silva Dal Pizzol T, Ramos LR, Mengue SS, Luiza VL, et al. Prevalência da automedicação no Brasil e fatores associados. Rev Saude Publica. 2016;50(supl 2):13s. doi: 10.1590/S1518-8787.2016050006117

11. Kaufmann CP, Stämpfli D, Hersberger KE, Lampert ML. Determination of risk factors for drug-related problems: a multidisciplinary triangulation process. BMJ Open. 2015;5:e006376. doi: 10.1136/bmjopen-2014-006376

12. Nguyen KV, Do NTT, Chandna A, Nguyen TV, Pham CV, Doan PM, et al. Antibiotic use and resistance in emerging economies: a situation analysis for Viet Nam. BMC Public Health. 2013;13:1158. doi: 10.1186/1471-2458-13-1158

13. Santos I, Sarat CNF. Modalidades de aplicação da teoria do autocuidado de Orem em comunicações científicas de enfermagem brasileira. Rev Enferm UERJ [Internet]. 2008[cited 21 May 2019];16(3):313-8. Available from: https://pesquisa.bvsalud.org/portal/resource/pt/bde-15146

14. Bennadi D. Self-medication: a current challenge. J Basic Clin Pharma. 2014;5:19-23. doi: 10.4103/0976-0105.128253

15. Phalke VD, Phalke DB, Durgawale PM. Self-medication practices in rural Maharashtra. Indian J Community M. 2006; 31(1):34-5. doi: 10.4103/0970-0218.54933 
16. González-López JR, Rodríguez-Gázquez MA, Lomas-Campos MM. Self-medication in adult Latin American immigrants in Seville. Acta Paul Enferm [Internet]. 2012 [cited 2019 Jun 05];25:75-81. Available from: http://www.scielo.br/pdf/ape/v25nspe2/pt_12.pdf

17. Nayir T, Okyay RA, Yesilyurt H, Akbaba M, Nazlıcan E, Acık Y, et al. Assessment of rational use of drugs and self-medication in Turkey: a pilot study from Elazıg and its suburbs. Pak J Pharm Sci [Internet]. 2016 [cited 2016 Sep 13];29(4 Suppl):1429-35. Available from: https://www. ncbi.nlm.nih.gov/pubmed/27592477

18. Carrasco-Garrido P, Hernandez-Barrera V, Lopez de Andres A, Jimenez-Trujillo I, Jimenez-Garcia R. Sex - Differences on self-medication in Spain. Pharmacoepidemiol Drug Saf. 2010;19(12):1293-9. doi: 10.1002/pds.2034

19. Jimenez Rubio D, Hernandez Quevedo C. Differences in self-medication in the adult population in Spain according to country of origin. Gac Sanit. 2010;24(2):116.e1-8. doi: 10.1016/j.gaceta.2009.09.007

20. Haseeb A, Bilal M. Prevalence of using non prescribed medications in economically deprived rural population of Pakistan. Arch Public Health. 2016;74. doi: 10.1186/s13690-015-0113-9

21. Lawan UM, Abubakar IS, Jibo AM, Rufai A. Pattern, awareness and perceptions of health hazards associated with self-medication among adult residents of kano metropolis, northwestern Nigeria. Indian J Community Med. 2013;38(3):144-51. doi:10.4103/0970-0218.116350

22. Ahmad A, Patel I, Mohanta G, Balkrishnan R. Evaluation of self-medication practices in rural area of town sahaswan at northern India. Ann Med Health Sci Res. 2014;4(Suppl 2):S73-8. doi: 10.4103/21419248.138012

23. Barros e Sá M, Barros JAC, Sá MPBO. Automedicação em idosos na cidade de Salgueiro-PE. Rev Bras Epidemiol. 2007;10(1):75-85. doi: $10.1590 /$ S1415-790X2007000100009

24. Carvalho e Martins MC, Leal LMM, Souza Filho MD, Costa EM, Holanda LGM, Mesquita LPL, et al. Uso de medicamentos sem prescrição médica em Teresina, PI. ConScientiae Saúde [Internet]. 2011 [cited 2019 Jun 05];10(1):31-7. Available from: http://periodicos.uninove.br/ index.php?journal=saude\&page=article\&op=view\&path\%5B\%5D=2516\&path\%5B\%5D =1893

25. Oliveira MA, Francisco PM, Costa KS, Barros MB. Automedicação em idosos residentes em Campinas, São Paulo, Brasil: prevalência e fatores associados. Cad Saúde Publica. 2012;28(2):335-45. doi: 10.1590/S0102-311X2012000200012

26. Santos TRA, Lima DM, Nakatani AYK, Pereira LV, Leal GS, Amaral RG. Consumo de medicamentos por idosos, Goiânia, Brasil. Rev Saúde Pública. 2013;47(1):94-103. doi: 10.1590/S0034-89102013000100013

27. Braoios A, Pereira AC, Bizerra AA, Policarpo OF, Soares NC, Barbosa AS. Uso de antimicrobianos pela população da cidade de Jataí (GO), Brasil. Cien Saúde Colet. 2013;18(10):3055-60. doi: 10.1590/S1413-81232013001000030

28. Widayati A, Suryawati S, de Crespigny C, Hiller JE. Self medication with antibiotics in Yogyakarta City Indonesia: a cross sectional populationbased survey. BMC Res Notes. 2011;4:491. doi: 10.1186/1756-0500-4-491

29. Ateshim Y, Bereket B, Major F, et al. Prevalence of self-medication with antibiotics and associated factors in the community of Asmara, Eritrea: a descriptive cross sectional survey. BMC Public Health. 2019;19:726. doi:10.1186/s12889-019-7020-x

30. Instituto Brasileiro de Geografia e Estatística-IBGE. Amazonas: panorama. Brasília: IBGE; 2017 [cited 2017 Aug 13]. Available from: https:// cidades.ibge.gov.br/brasil/am/panorama

31. Ministério da Saúde (BR). Cadastro Nacional de Estabelecimentos de Saúde (CNES). Estabelecimento de saúde do município: Coari[Internet]. 2016[cited 2016 Jun 07]. Available from: http://cnes2.datasus.gov.br/Lista_Es_Municipio.asp?VEstado=13\&VCodMunicipio=130120\&Nome Estado=AMAZONAS

32. World Health Organization-WHO. Colaborating Centre for Drug Statistic methodology. Use of ATC/DDD[Internet]. Oslo: Norwegian Institute of Public Health; 2011 [cited 2016 Jun. 07]. Available from: http://www.whocc.no/use_of_atc_ddd/

33. Gama ASM, Secoli SR. Automedicação em estudantes de enfermagem do Estado do Amazonas - Brasil. Rev Gaúcha Enferm. 2017;38(1):e65111. doi: 10.1590/1983-1447.2017.01.65111

34. Oliveira APC, Gabriel M, Poz MRD, Dussault G. Desafios para assegurar a disponibilidade e acessibilidade à assistência médica no Sistema Único de Saúde. Ciênc Saúde Coletiva. 2017;22(4):1165-1180. doi: 10.1590/1413-81232017224.31382016

35. Medeiros DS, Moura CS, Guimaraes MD, Acurcio FA. Utilização de medicamentos pela população quilombola: inquérito no sudoeste da Bahia. Rev Saúde Pública. 2013;47(5):905-13. doi: 10.1590/S0034-8910.2013047004817

36. Ministério da Saúde (BR). Resolução-RDC n²0, de 5 de maio de 2011. Dispõe sobre o controle de medicamentos à base de substâncias classificadas como antimicrobianos, de uso sob prescrição, isoladas ou em associação[Internet]. Brasília: Ministério da Saúde; 2011 [cited 2016 Oct 15]. Available from: http://www.anvisa.gov.br/sngpc/Documentos2012/RDC\%2020\%202011.pdf?jornal=

37. Gama ASM, Figueras A, Secoli SR. Inappropriately prescribed and over-thecounter antimicrobials in the Brazilian Amazon Basin: we need to promote more rational use even in remote places. PLoS ONE; 2018;13(8): e0201579. doi: 10.1371/journal.pone.0201579

38. Radyowijati A, Haak H. Improving antibiotic use in low-income countries: an overview of evidence on determinants. Soc Sci Med. 2003;57(4):733-44. doi: 10.1016/S0277-9536(02)00422-7

39. De Melo MN, Madureira B, Ferreira APN, Mendes Z, Miranda Ada C, Martins AP. Prevalence of self-medication in rural áreas of Portugal. Pharm World Sci. 2006;28:19-25. doi: 10.1007/s11096-005-2222-y

40. Martins PA, Miranda Ada C, Mendes Z, Soares MA, Ferreira P, Nogueira A. Self-medication in a Portuguese urban population: a prevalence study. Pharmacoepidemiol Drug Saf. 2002;11:409-14. doi: 10.1002/pds.711 